\title{
Mature T- and NK-Cell Lymphoma by Ann Arbor Stage
}

National Cancer Institute

\section{Source}

National Cancer Institute. Mature T-and NK-Cell Lymphoma by Ann Arbor Stage. NCI

Thesaurus. Code C141272.

An anatomic stage for mature T- and NK-cell non-Hodgkin lymphomas based on the Ann Arbor classification criteria. 